\title{
Deciphering Trichoderma-Plant-Pathogen Interactions for Better Development of Biocontrol Applications
}

\author{
Alsayed Alfiky ${ }^{1,2, *}$ and Laure Weisskopf ${ }^{1}$ (D) \\ 1 Department of Biology, University of Fribourg, Rue Albert-Gockel 3, 1700 Fribourg, Switzerland; \\ laure.weisskopf@unifr.ch \\ 2 Genetics Department, Faculty of Agriculture, Tanta University, Tanta 31511, Egypt \\ * Correspondence: alfiky@agr.tanta.edu.eg
}

check for updates

Citation: Alfiky, A.; Weisskopf, L. Deciphering Trichoderma-Plant -Pathogen Interactions for Better Development of Biocontrol Applications. J. Fungi 2021, 7, 61. https://doi.org/10.3390/jof7010061

Received: 24 December 2020 Accepted: 2 January 2021

Published: 18 January 2021

Publisher's Note: MDPI stays neutral with regard to jurisdictional clai$\mathrm{ms}$ in published maps and institutional affiliations.

Copyright: (C) 2021 by the authors. Licensee MDPI, Basel, Switzerland. This article is an open access article distributed under the terms and conditions of the Creative Commons Attribution (CC BY) license (https:// creativecommons.org/licenses/by/ $4.0 /)$.

\begin{abstract}
Members of the fungal genus Trichoderma (Ascomycota, Hypocreales, Hypocreaceae) are ubiquitous and commonly encountered as soil inhabitants, plant symbionts, saprotrophs, and mycoparasites. Certain species have been used to control diverse plant diseases and mitigate negative growth conditions. The versatility of Trichoderma's interactions mainly relies on their ability to engage in inter- and cross-kingdom interactions. Although Trichoderma is by far the most extensively studied fungal biocontrol agent (BCA), with a few species already having been commercialized as bio-pesticides or bio-fertilizers, their wide application has been hampered by an unpredictable efficacy under field conditions. Deciphering the dialogues within and across Trichoderma ecological interactions by identification of involved effectors and their underlying effect is of great value in order to be able to eventually harness Trichoderma's full potential for plant growth promotion and protection. In this review, we focus on the nature of Trichoderma interactions with plants and pathogens. Better understanding how Trichoderma interacts with plants, other microorganisms, and the environment is essential for developing and deploying Trichoderma-based strategies that increase crop production and protection.
\end{abstract}

Keywords: fungal chemical ecology; Trichoderma; mutualistic; mycoparasitism; plant defense; ISR; secondary metabolite; volatile organic compounds (VOC)

\section{Introduction}

Heavy reliance on synthetic pesticides and fertilizers to support crop production has negatively impacted the environment and the health of humans and ecosystems [1,2]. Judicious exploitation of beneficial plant-microbe partnerships that have been evolutionally fine-tuned can help sustainably meet steadily increasing global demand for plant products. Biocontrol of plant diseases represents the most widely deployed form of such applications. Certain bacteria (e.g., Pseudomonas, Paenibacillus, Streptomyces, Bacillus) and fungi (e.g., Trichoderma, Glomus) confer one or more of the following benefits to plants: (a) protection from diverse pathogens and pests both directly (suppression of their growth or parasitism) and indirectly (induction of plant defense); (b) increased abiotic stress tolerance; and (c) enhanced growth. Trichoderma is one of the most extensively studied biocontrol agents (BCAs). The versatile lifestyle and nutritional adaptability of Trichoderma spp. enable members of the genus to occupy a wide range of ecological niches. Several species have proven able to form partnerships with different host plants as beneficial avirulent symbionts or endophytes [3-5]. Symbiotic relationships between host plants and Trichoderma spp. provide both parties with benefits. Trichoderma-based products have been commercialized as biocontrol agents (BCAs) to control a wide assortment of crop pathogens and as bio-fertilizers or growth-enhancers to promote plant growth [6]. The host plant roots provide Trichoderma with a suitable habitat and food; in return, they gain positive modulation of growth, yield, and stress tolerance. In complex multi-species communities sharing the same ecological niche, several important inter- and cross-kingdom communications are expected to take 
place [7-9]. Enhanced understanding of the molecular mechanisms underlying Trichoderma-plant and -fungal interactions is fundamental to judiciously harness Trichoderma full potential to support plant growth and health. Here, we reviewed how Trichoderma spp. directly and indirectly affects plant growth and health.

\section{Trichoderma-Plant Interactions}

As opportunistic, avirulent plant symbionts, Trichoderma spp. have developed a wide array of strategies to build a mutually beneficial relationship with plants. This form of crosskingdom communication is achieved through chemical signaling, in which fungi produce chemical compounds that alter plant transcriptome, proteome, and metabolome $[10,11]$. The outcome of such interactions is often favorable for plants in the form of improved growth and elevated tolerance to biotic and abiotic stresses. In this context of interactions, Trichoderma secretes a plethora of effectors to modulate plant growth and immunity. Proteins, small RNAs and different classes of secondary metabolites (SM) including VOCs (volatile organic compounds) have been documented to play different critical roles in Trichoderma-plant interactions [12].

\subsection{Trichoderma as Plant Growth Regulators}

Having the ability to regulate plant growth and physiology is a key feature of several members of the genus Trichoderma. They exert such effect through their abundant secretome of which specific proteins and SMs were found to target specific plant components regulating different physiological processes (Table 1). Trichoderma-mediated plant growth regulation could either be the direct effect of released molecules on plants or, indirect effect to Trichoderma's impact and modification of the surrounding environment, e.g., modifying soil microbiome or lowering soil $\mathrm{pH}$ making the macro- and micronutrients more available to plants [13]. Such ability of Trichoderma spp. to regulate key pathways and physiological processes in plants could prove to be vital, especially under stress conditions where Trichoderma spp. can help alleviate such pressure. T. yunnanense and T. afroharzianum were reported to have the ability to enhance net photosynthesis, water use efficiency. and increased wheat (Triticum aestivum L.) biomass under salt stress [14]. Similarly, T. longibrachiatum ameliorated the negative effects of salt on wheat growth through activation of the antioxidative defense systems [15]. Many recent reports have detailed the ability of Trichoderma spp. to modulate physiological, biochemical, and molecular mechanisms in a wide assortment of plants under various growth conditions, all of which have indicated the huge potential of members of this genus to be used as biostimulants, biofertilizers, and biocontrol agents in agriculture [16-19].

\subsubsection{Root Colonization by Trichoderma spp.}

The uncovered molecular dialogue between host plants and Trichoderma during root colonization revealed interesting mechanisms of cross-kingdom communications. During the asymptomatic colonization of plant roots by Trichoderma, the host plant activates several physical or biochemical responses, which limit the invading fungus to a few root cortical cell layers in plant roots. These responses include reinforcing and modifying plant cell walls, as well as producing reactive oxygen species and antimicrobial SMs [20-23]. The accumulated evidence suggests that Trichoderma have evolved ingenious mechanisms to hijack the hormone-regulated plant immunity in order to establish a prolonged mutualistic association. Trichoderma achieves host tolerance by suppressing plant defenses through the action of various effectors [23]. Trichoderma-mediated global transcriptome and proteome changes in plants have been recorded and their effect on development, growth modulation, and defense were at the center of several recent articles [24-27]. Research in this area has provided several meaningful insights revealing sophisticated molecular mechanisms of interaction between Trichoderma and their host plants [28-30]. It was reported that T. virens reduced maize (Zea mays L.) secretome by $36 \%$ during root colonization including major families of glycosyl hydrolases and peroxidases participating in plant defense against 
microbial invasion. In return, T. virens secretes a plethora of proteins and SMs performing different functions to establish root colonization in a synergistic synchronized manner. Such functions include secretion of cell wall degrading enzymes to facilitate entry to plant roots, antioxidant proteins to counteract the plant defense-induced oxidative burst consisting of superoxide, hydroxyl radical and hydrogen peroxide and several SMs and effector-like proteins that interfere with the homeostasis of plant hormones playing important roles in defense [31]. In a similar manner, extended transcriptome changes in Arabidopsis thaliana associated with transient repression of the plant immune responses and downregulation of defense genes in the roots was reported during T. asperelloides root colonization [32]. In agreement with these findings, defense-related genes in aerial parts of $A$. thaliana under the control of the salicylates-salicylic acid (SA) and jasmonic acid (JA) signaling pathways appeared to be downregulated during the early stage of root colonization by T. harzianum [33]. Proteome changes in shoots of maize during root colonization by T. harzianum showed that although T. harzianum was only present in roots, numerous proteins (including those involved in biotic and abiotic responses) were induced in foliar tissues [34]. Comparison between T. harzianum-treated, Ganoderma boninense-treated, and untreated palm oil plants for transcriptome dynamics revealed that three 1-aminocyclopropane-1-carboxylate (ACC) oxidase genes were downregulated, while another was upregulated in Trichoderma-treated oil palm roots compared to those of untreated plants. Although the same enzymes were activated in Ganoderma-treated plants, a different set of genes was activated in Trichoderma-treated plants, which suggests that elicited plant genes are differentially regulated by different fungal signals. The genes encoding 12-oxo-phytodienoic reductase were downregulated in Trichoderma-treated oil palm roots, indicating the downregulation of JA biosynthesis. Moreover, 12-oxo-phytodienoic acid is a cyclopentenone precursor of JA required for the wounding response [35] and the downregulation of the enzymes might therefore account for the asymptomatic colonization of plant roots by Trichoderma [35]. Taken together, these findings suggest that Trichoderma induce broad-spectrum suppression of host plant innate immunity in an attempt to maneuver and evade the plant defense responses during the initial stages of the interaction to successfully colonize the roots and establish a symbiotic relationship with the Plant

\subsubsection{Alteration of Plant Hormonal Homeostasis}

Plant hormones play pivotal roles in the regulation of the complex and interconnected immune signaling networks, providing a huge potential for rapid response and adaptation to various conditions [36]. Moreover, the finely tuned plant hormonal homeostasis required for proper development, reproduction, and response to various stress conditions can be influenced by microorganisms synthesizing phytohormones. Phytohormones include different categories such as auxins, cytokinins, ethylene (Et), gibberellins, and abscissic acid (ABA), as well as hormone-like substances such as brassinosteroid, oligosaccharines, bioamines, salicylates-salicylic acid (SA), and jasmonic acid (JA) [37]. Microbially-derived phytohormones can help plants withstand biotic and abiotic stress conditions. The roles of exogenous phytohormone supplementation through plant-microbe interaction has been the focus of numerous studies [38-41]. Perception of Trichoderma's secretome by plant roots is a first step in chain reactions that directly interfere with plant growth and physiology (Figure 1). Several members of Trichoderma spp. can produce phytohormones (auxin, gibberellin) and the enzyme 1-aminocyclopropane-1-carboxylic acid (ACC) deaminase can regulate the level of plant ethylene [37]. Moreover, volatiles from T. asperellum IsmT5 upregulated the plant SA production by $61 \%$ and ABA by $40 \%$ compared to plants not exposed to volatiles [42]. Isolates of different Trichoderma spp. which promote plant growth was shown to influence the phytohormone signature in melon plants, which led to increased auxin and decreased cytokinin and ABA contents. By evaluating the relationship between observed plant phenotype and hormonal variables, principal component analysis suggested strong association between auxin induction and Trichoderma-induced plant growth promotion [43]. These results suggest that alteration of plant hormonal homeostasis 
is a key mechanism by which Trichoderma can interfere with plant physiology and improve plant fitness.

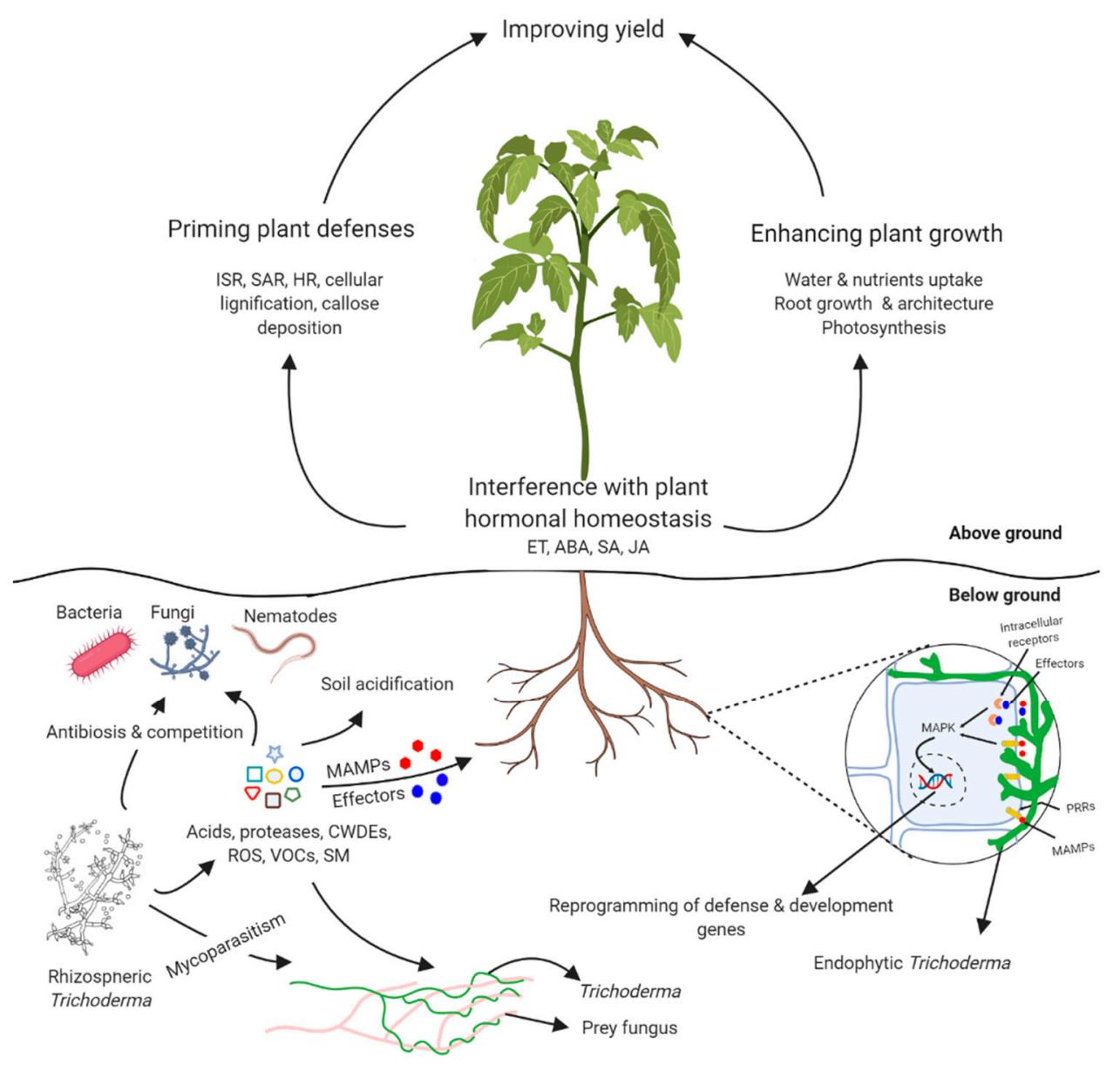

Figure 1. Trichoderma-plant-pathogen interactions map. Trichoderma produces recognition molecules, i.e., MAMPS (microbe-associated molecular patterns) and effectors, which bind to the PRRs (pattern recognition receptors) and intracellular receptors activating mitogen-activated protein kinase (MAPK) cascades, leading to the reprogramming of several plant pathways related to defense, i.e., induced systemic resistance (ISR), systemic acquired resistance (SAR), and hypersensitive response (HR), as well as interfering with hormonal homeostasis, i.e., ethylene (ET), abscisic acid (ABA), salicylic acid (SA), and jasmonic acid (JA) pathways. Trichoderma-pathogen interactions takes several forms through the action of its diverse secretome containing volatile organic compounds (VOC), cell wall degrading enzymes (CWDE), reactive oxygen species (ROS), and antimicrobial secondary metabolites (SM). By forming these interactions, Trichoderma increases plant fitness and tolerance against biotic stress either by priming plant defenses, increasing plant growth, or releasing pathogen pressure leading to the enhanced growth response.

\subsubsection{Trichoderma-Produced VOCs as Plant Growth Regulators}

In addition to direct root colonization and the emission of non-volatile compounds, the release of VOCs produced by Trichoderma can also alter plant growth and development. Several studies on the effects of VOCs from different Trichoderma spp. or strains on plant growth and physiology revealed that the effect is likely strain/species-specific. Volatiles from certain Trichoderma spp. and strains improved A. thaliana growth, plant biomass, chlorophyll content, and lateral root formation, while VOCs emitted by other species and strains had a negative effect [44]. Similar findings were reported for VOCs from T. asperellum $\mathrm{T} 1$ on lettuce plants as positive correlation between T1 VOCs and plant growth traits was reported [45]. Similarly, in another study, it was reported that Trichoderma VOCs 
were found responsible for inducing root branching and root hair formation in a manner similar to the changes observed in plants exposed to low iron availability [46]. Analysis confirmed that Trichoderma's volatile compound 6-pentyl-2H-pyran-2-one (6PP) promoted plant growth and regulated root architecture in a specific and dose-dependent manner [47]. Through genetic screening of wild type seedlings, as well as auxin- and ethylene-related mutants, A. thaliana genes controlling root architectural responses to 6PP were identified and the results suggest that root responses to 6-PP involve components of auxin transport and signaling, and the ethylene-response modulator EIN2.

Table 1. Example of molecules secreted by Trichoderma spp. that modulate plant growth, defense, and physiology.

\begin{tabular}{|c|c|c|c|c|}
\hline Molecule & Producer & Tested Plant & Effect and Known or Suggested Mode of Action & $\begin{array}{l}\text { Reference } \\
\text { Number }\end{array}$ \\
\hline \multicolumn{5}{|c|}{ Volatile } \\
\hline $\begin{array}{l}\text { 6-pentyl- } \alpha \text { - } \\
\text { pyrone } \\
(6 \mathrm{PP})\end{array}$ & T. asperellum & Arabidopsis & $\begin{array}{c}\text { Pre-exposure activated defense responses and reduced } \\
\text { symptoms against Botrytis cinerea and } \\
\text { Alternaria brassicicola }\end{array}$ & {$[42]$} \\
\hline $6 \mathrm{PP}$ & $\begin{array}{l}\text { T. harzianum } \\
\text { T. atroviride }\end{array}$ & Tomato & $\begin{array}{l}\text { Increased plant height, leaf area, developed roots system, } \\
\text { and lycopene content in fruits }\end{array}$ & {$[48,49]$} \\
\hline 1-octen-3-ol & T. virens & Arabidopsis & $\begin{array}{l}\text { Enhanced plant resistance against pathogens by } \\
\text { activating JA/ET-dependent defense pathways }\end{array}$ & {$[50,51]$} \\
\hline Trichodiene & T. harzianum & Tomato & $\begin{array}{l}\text { Upregulated defense related genes in plants especially } \\
\text { the SA-related genes. }\end{array}$ & {$[52,53]$} \\
\hline \multicolumn{5}{|c|}{ Non-volatile } \\
\hline $\begin{array}{l}\text { Xylanase } \\
\text { Xyn2/Eix }\end{array}$ & T. viride & Tobacco, Tomato & $\begin{array}{l}\text { Elicited ethylene biosynthesis and } \\
\text { hypersensitive responses }\end{array}$ & {$[54]$} \\
\hline $\begin{array}{c}\text { Hyd1 } \\
\text { hydrophobin }\end{array}$ & T. harzianum & Maize & Elicited plant defense responses & [55] \\
\hline Cellulases & T. harzianum & Maize & Induced ISR in plants via ET or JA pathways & [56] \\
\hline $\begin{array}{l}\text { Isoharzianic acid } \\
\text { (iso-HA) }\end{array}$ & T. harzianum & Tomato & $\begin{array}{l}\text { Improved seed germination and induced } \\
\text { disease resistance. }\end{array}$ & {$[57]$} \\
\hline Harzianolide & T. harzianum & Tomato & $\begin{array}{l}\text { Promoted seedling growth and induced expression of } \\
\text { defense related genes. }\end{array}$ & [58] \\
\hline $\begin{array}{l}\text { hydrophobin-like } \\
\text { elicitor (SM1) }\end{array}$ & T. virens & $\begin{array}{l}\text { Maize } \\
\text { Cotton }\end{array}$ & Induced defense against plant pathogens. & {$[59,60]$} \\
\hline Epl1 & $\begin{array}{l}\text { T. asperellum } \\
\text { T. harzianum }\end{array}$ & PdPap, Tomato & $\begin{array}{c}\text { Elicited plant defense } \\
\text { Altered B. cinerea virulence }\end{array}$ & {$[61,62]$} \\
\hline Swollenin & T. asperellum & Cucumber & $\begin{array}{l}\text { Enhanced local defense responses and plant root } \\
\text { colonization by Trichoderma. }\end{array}$ & [63] \\
\hline Hydrophobin & $\begin{array}{l}\text { T. longibrachia- } \\
\text { tum }\end{array}$ & Tobacco, Tomato & $\begin{array}{l}\text { Elicited ISR and activated defense-related responses } \\
\text { involving ROS and other compounds and stimulated } \\
\text { root formation and growth. }\end{array}$ & [64] \\
\hline Harzianic acid & T. harzianum & Tomato & $\begin{array}{l}\text { Enhanced plant growth and increased seed } \\
\text { germination rate }\end{array}$ & [57-65] \\
\hline Cremenolide & T. cremeum & Tomato & Promoted plant growth & [66] \\
\hline
\end{tabular}

\subsection{Induction of Plant Defenses by Trichoderma}

Having to endure several biotic stresses from invading pathogens such as bacteria, fungi, or insects, which negatively impact growth and disrupt vital physiological processes, plants have evolved multiple mechanisms to counteract the prejudicial effect associated with such stress. Given that biological agents are far from being equal in terms of their modes of action and impact on plant health, plants have developed several scenarios 
to appropriately respond to microbial invasion. During some scenarios, plant defense responses are limited to the local infection areas, while other scenarios include upgrading the defense readiness of the entire Plant Within this second type of scenario, plants upgrade their defenses in tissues not affected by the initial attack to ward off secondary waves of attack, conferring a fitness advantage. In particular, two of the most extensively studied mechanisms for plant induced defenses are pathogen-induced systemic acquired resistance (SAR) and induced systemic resistance (ISR) triggered by mutualistic microbes such as Trichoderma spp. [60,67]. A significant body of recent literature has documented the potentiation and stimulation of plant defense responses by Trichoderma spp. [68-70]. In addition to their ability to directly antagonize plant pathogens and promote plant growth, several Trichoderma spp. can interfere with signaling networks in their host plants to improve disease resistance and stress tolerance. Chili pepper (Capsicum annum L.) treated with T. harzianum (as foliar spray), T. asperellum (as seed treatment) or combined application displayed enhanced defense and immunity against the fungal pathogen Colletotrichum truncatum through reprogramming of plant defense network in a strain- and applicationdependent manner [27]. In pathogen presence, either single or dual consortia-treated chili plants showed varying augmentation of phenolic compounds such as caumeric acid, capsaicin, myrcetin, salicylic acid, and quercetin, which correlated with enhanced host plant immunity. The two Trichoderma spp. applied through different methods differentially affected expression of plant defense genes PR1 and PR2, indicating that both strains have different ways of eliciting plant immune response.

To reveal the mechanisms by which T. hamatum induces tomato (Solanum lycopersicum L.) resistance to the bacterial pathogen Xanthomonas euvesicatoria, high density oligonucleotide microarray analysis revealed 41 differentially expressed genes associated with stress, cell wall modification, and signaling as well as RNA, DNA, and protein metabolism [71]. T. harzianum Epl-1, a protein elicitor of the cerato-platanin protein family, elicited the expression of genes involved in the SA defense pathway in tomato plants in the presence or absence of the pathogen. This elicitor also downregulated the expression of virulence genes of Botrytis cinerea especially those involved in the biosynthesis of botrydial, an important phytotoxic sesquiterpene metabolite, suggesting a key role for this protein in T. harzianum biocontrol interactions [62].

Pathogen-associated molecular patterns (PAMPs) or microbe-associated molecular patterns (MAMPs) refer to pathogenic or microbial effectors associated with plant health, development, and physiology [72]. ISR activation is a key outcome in plants triggered with MAMPs [73]. Plant recognition of microbial effectors by pattern-recognition receptors (PRRs) is considered the first step towards an effective immune response [74]. These PRRs play important roles in the perception of evolutionarily conserved (e.g., flagellin and chitin) or species-specific (e.g., ethylene-inducing-xylanase from T. viride) microbial effectors, wherein they transmit signals to trigger the PAMP/MAMP immune response [72,74].

T. harzianum treatment reduced disease severity and enhanced immunity and grapevine defense against Plasmopara viticola, the causal agent of grapevine downy mildew without directly inhibiting $P$. viticola sporangia germination, in a manner similar to the effect of SAR inducer benzothiadiazole (BTH) [75]. Comprehensive proteome analysis for T. harzianum induced resistance in grapevine revealed that most affected proteins belonged to signal transduction pathways suggesting MAMP-triggered immunity accompanied with rapid production of ROS and callose at infection sites [76]. Several studies aimed to dissect the molecular dialogue underlying the plant immune response to Trichoderma's effectors. In this regard, it was confirmed that Trichoderma spp. are potent producers of lytic enzymes such as cellulases breaking down plant cell walls. Trichoderma cellulases have also been reported to induce ISR in plants via ET or JA pathways [77,78]. Consistently, the cellulaselike proteins Thph1 and Thph2 from T. harzianum triggered ISR in maize leaves while fungal $\Delta \mathrm{Th} h \mathrm{~h} 1$ - or $\Delta \mathrm{Thph} 2$-deletion mutant failed to activate maize immune response against an attack by the pathogenic fungus Curvularia lunata [56]. Moreover, the transcription factor MYB72 was upregulated in A. thaliana roots upon colonization by T. asperellum, while 
A. thaliana myb72 mutants failed to express Trichoderma-triggered ISR against different shoot pathogens, indicating an essential role for MYB72 in the onset of Trichoderma-induced ISR in plants [79]. Elicitation of systemic immunity against downy mildew and modulation of pearl millet physiology in response to association with T. hamatum was also reported [80]. Cell wall lignification and callose deposition in addition to enhanced activities of several defense enzymes such as glucanase, peroxidase, phenylalanine ammonia-lyase, and polyphenol oxidase were observed in T. hamatum- treated plants in comparison to the untreated control. The increased activities of several SA-inducible genes such as glucanase, peroxidase, polyphenol oxidase, phenylalanine ammonia-lyase, and hydroxyproline-rich glycoproteins suggest a possible link between accmulation of SA in Trichoderma- treated plants and systemic resistance.

Trichoderma-mediated induction of plant defenses provides protection against invading microbial pathogens of diverse classes as well as insects and nematodes. Pre-treatment of $A$. thaliana seedlings with Trichoderma VOCs induced protection against B. cinerea and reduced disease severity and pathogen proliferation in the leaves three weeks after transplanting. Interestingly, micrografting of plant roots exposed to Trichoderma VOCs on a non-exposed scion revealed that the perception of the volatile signals by the roots was necessary to prime plant shoot defense mechanisms in a systemic manner [46]. Strains of T. viride and T. harzianum with biocontrol potential to protect rice plants (Oryza sativa L.) against Rhizoctonia solani induced detrimental morphological and physiological changes in the pathogen hyphae, including swelling, knotting, crumpling, flattening, shriveling, bursting, and cytoplasm leaking. Furthermore, accumulation of defense-related biomolecules in plants such as phenylalanine ammonia lyase (PAL), peroxidase, $\beta$-1,3-gluconase, chitinase, total phenolics content, polyphenol oxidase, and superoxide dismutase was also reported [81].

In addition to the response of plants to pathogens, Trichoderma can also induce plant defense against insect attack by the activation of plant defense-related pathways [82,83]. T. harzianum induced metabolic changes in tomato plants that indirectly counteracted the attack by the aphid Macrosiphum euphorbiae by attracting the parasitoid Aphidius ervi [84]. The concomitant presence of T. harzianum on plant roots and of aphids on the leaves induced parasitoid attraction towards the infested plants and the plants were shown to produce a different VOC profile in the presence of both Trichoderma and aphids than when either of them were alone, which may account for the observed changes of parasitoid flight behavior. Similar findings were obtained with T. longibrachiatum, which modified the VOCs released by tomato plants resulting in increased attractiveness to the natural enemies of the aphid M. euphorbiae [85].

\section{Direct Interactions with Plant Pathogens}

Microbial communities in the rhizosphere, including beneficial microbes and detrimental pathogens, are constantly competing for finite resources, such as limited space in soil or plant roots, as well as soil nutrients. Having an augmented arsenal of cell wall degrading enzymes (proteases, chitinases, lipases, glucanases, etc.), antibiotic SMs, powerful secretory, and cellular detoxification systems, in addition to their high adaptability to different environments, being heavily sporulating and fast growing are all factors contributing to establish and confirm the position of several Trichoderma spp. as "soil competent BCAs" against a wide spectrum of plant pathogens [86-89]. The powerful biocontrol machinery of Trichoderma spp. has been the main drive for exploring the efficacy of different species/isolates as potential BCAs, either as prophylactic or curative treatments against plant pathogens, especially when chemical fungicide treatments have proven to be ineffective or economically unfeasible. Different T. harzianum isolates were reported to successfully shield soybean (Glycine max L.) against charcoal rot disease caused by the soilborne pathogen Macrophomina phaseolina [90]. Tolerance to chemical fungicide is a prerequisite for Trichoderma spp. to join integrated pest management programs; therefore, evaluation of Trichoderma spp. resistance/tolerance to chemical fungicides and using vari- 
ous mutagenesis techniques to produce mutants with elevated fungicide-resistance was the center of numerous studies with promising results [91-93]. Through different mechanisms such as competition, antibiosis, and mycoparasitism, Trichoderma can directly antagonize plant pathogens relieving associated plants from their biotic stress and providing healthier growth conditions [94,95]. Mycoparasitism is a form of biotrophic interaction in which fungal parasites stay alive on the expense of other fungal hosts [96]. Successful commercialization of several Trichoderma BCAs relied heavily on their mycoparasitic ability to detect, antagonize, or kill other fungi. The process of mycoparasitism appears to be very complex, shared by several Trichoderma spp., but still involves host specific steps of first, detection of host fungi and later, unleashing a set of hydrolytic enzymes and mycotoxic secondary metabolites. Several genomic studies focusing on investigating the nature and mechanisms of mycoparasitism revealed that some species have larger arsenals of genes encoding hydrolytic enzymes and antifungal compounds [96,97], which might at least partially explain the variable biocontrol performance of different Trichoderma spp.

\subsection{Early Perception of Host-Derived Signals Is Critical for Successful Mycoparasitism}

At the molecular level, a crucial factor for successful mycoparasitism is the early detection of host signals. The molecular mechanisms underlying the activation of the biocontrol machinery in Trichoderma have been analyzed, and the currently accepted model suggests that lytic enzymes and antimicrobial secondary metabolites produced by Trichoderma in combination with the formation of infection structures are triggered by the presence of Trichoderma's foes [98-100]. Such activation can only take place after Trichoderma either perceives host-derived external signals (e.g., components of the host cell wall, secreted metabolites) or experiences physical interaction with ligands located on the host surface [99]. Both T. atroviride and T. virens responded to Rhizoctonia solani already before any physical contact by activating mycoparasitism-related genes, which supports the hypothesis that diffusible host-released substances trigger the BCA's antagonistic response [96]. Volatile organic compounds (VOCs), which are low molecular weight compounds comprising aliphatic and aromatic hydrocarbons, ketones, alcohols, esters, aldehydes, terpenes and other classes [101,102], might also be involved in such long-distance recognition. Indeed, VOCs emitted by other microorganisms were shown to affect the secretion of antibacterial and antifungal molecules in Trichoderma [103,104].

\subsection{Mycoparasitism in Trichoderma Is a Conserved Mechanism with a Host-Dependent Processes}

Transcriptome analysis revealed that different Trichoderma spp. upregulate both a common and a distinct set of genes during their contact with fungal pathogens pointing to the existence of alternative strategies to attack their hosts $[105,106]$. Gene expression analysis in T. harzianum upon interaction with the four fungal pathogens Fusarium oxysporum, Colletotrichum capsici, Colletotrichum truncatum, and Gloesercospora sorghi revealed significantly different responses to different hosts [107]. Using a computational approach, an algorithm was designed to predict potential effector proteins from T. virens, T. atroviride, and T. reesei [108]. One of the identified genes, tacfem1, an encoded protein with a CFEM (common in fungal extracellular membranes) domain, was upregulated during interaction with $R$. solani AG5 but not in the presence of $R$. solani AG2, revealing a host-specific response pattern. Heterotrimeric $G$ proteins are important intracellular signaling proteins that participate in the perception of host signals as they activate the mycoparasitic attack in Trichoderma spp. [95,109-111]. They are activated by canonical G-protein coupled receptors (GPCRs) upon ligand binding $[112,113]$. It was shown that T. atroviride mutants missing tga3, a G-protein $\alpha$ subunit-encoding gene, were avirulent in direct confrontation assays with $R$. solani or $B$. cinerea, as they failed to secrete mycoparasitism-relevant hydrolytic enzymes and were unable to attach to host hyphae and form mycoparasitism-related infection structures in response to the host, suggesting a general role for Tga3 in host recognition [109]. Another gene with a possible role in the recognition of host-derived signals by T. atroviride is gpr1, which encodes a seven-transmembrane domain receptor belonging to the cAMP 
receptor-like class of fungal GPCRs [100]. Silenced gpr1 transformants were avirulent in confrontation assays. Similar to $\Delta \operatorname{tg} a 3$ mutants, they failed to attach to and attack their host fungi and were unable to induce the expression of the cell wall degrading enzymes upon contact with $R$. solani. Interestingly, the addition of exogenous cAMP to the confrontation plates was enough to restore the abilities for attachment and coiling around host hyphae in $\Delta t g a 3$ and gpr1-silenced strains. These findings indicate a role for gpr1 in detecting host-derived signals and in activating intracellular regulatory targets, which results in activation of mycoparasitism-related features in T. atroviride via the cAMP pathway.

\subsection{Trichoderma Proteins with Important Roles in Biocontrol}

The lifestyle and biological functions of filamentous fungi are dictated by their ability to secrete extracellular effectors highlighting the importance of proteomic and metabolomic analysis to identify determinants playing key roles in Trichoderma spp. interactions and biocontrol efficacy. Several approaches for proteome analysis have been used to investigate and compare proteins produced by different members of Trichoderma spp. under a wide range of growth conditions [31,114-117]. A novel aspartic protease was identified and found to be differently upregulated in T. harzianum cultures amended with different fungal cell walls, suggesting a role in mycoparasitism and a proteomic response tuned to the fungal partner [118]. Proteome analysis of T. harzianum grown in the presence or absence of Fusarium solani or B. cinerea cell walls showed elevated protein content in pathogencell wall amended media with upregulated proteins belonging to mycoparasitism-related functions, such as chitinases, $\alpha$ and $\beta$ 1,3-glucanases, glucoamylases, and proteases, suggesting that pathogen cell wall is indeed a main target of T. harzianum in the biocontrol mechanism $[119,120]$.

\subsection{The Roles of VOCs Released from Trichoderma in Microbial Interactions.}

In addition to proteins, Trichoderma spp. produce a variety of secondary metabolites, including VOCs, which serve as info semiochemicals for protection and communication [48]. The use of antimicrobial VOCs from fungal biocontrol agents to inhibit microbial growth (mycofumigation) is a promising alternative to chemical fumigation. A significant body of recent literature aimed to evaluate the potential of different Trichoderma strains as producers of antimicrobial VOCs. Headspace analysis for VOCs from different members of Trichoderma spp. revealed inter- and intra-species variations for the ability to produce 6-n-pentyl-2H-pyran-2-one (6-PAP or 6PP) [121]. The volatile compound 6PP plays a key role in Trichoderma-plant interaction as it inhibits several phytopathogenic fungi, promotes plant growth, and alters root architecture inhibiting primary root growth and inducing lateral root development [48]. Additional volatile compounds identified from different Trichoderma spp. include hydrocarbons, alcohols, lactones, furanes, ketones, aldehydes, alkanes, alkenes, esters, aromatic compounds, heterocyclic compounds, and various terpenes [44,122-124]. Similarly, VOCs with antagonistic activities against several root-rot fungi were identified from T. gamsii [124].

\subsection{Trichoderma Non-Volatile Metabolites and Their Role in Biocontrol}

The ability of various members of Trichoderma spp. to produce secondary metabolites with antibiotic activity has attracted the attention of many researchers for a long time and, in addition to the VOCs mentioned above, various classes of SMs have been identified (e.g., non-ribosomal peptides such as peptaibiotics, siderophores, diketopiperazines-like gliotoxin/gliovirin, polyketides, terpenes, and isocyane metabolites) [88,125-127]. For more details regarding different SMs produced by different Trichoderma spp., we refer the reader to a recent review by Li et al., 2019 [128]. Although the mechanisms of interaction with plants and microbes are not fully elucidated yet for all identified SMs, it is believed that these compounds play important roles during biocontrol events due to their antimicrobial activities, which allows them to serve in chemical warfare against competitors and host fungi, while at the same time exhibiting plant growth-promoting and plant resistance- 
inducing activities $[129,130]$. Harzianic acid and harzianolide produced by T. harzianum were found to promote plant growth and harzianic acid, a tetramic acid with siderophorelike activity, which also inhibited diverse phytopathogens, including Pythium irregulare, Sclerotinia sclerotiorum, and R. solani [57,58,65].

The non-ribosomal synthesized peptaibols are a class of SMs that is specific to the mycoparasitic lineages of Hypocreales. These fungal oligopeptides (7-20 amino acids) are characterized by the presence of the nonproteinogenic amino acid alpha-aminoisobutyric acid (AIB) and generally exhibit antimicrobial activity against fungi and gram-positive bacteria $[131,132]$. Their antibiotic activity is based on membrane insertion of the peptaibol, which has a helical structure and forms ion channels and pores in the lipid bilayer [133]. Peptaibols were further shown to act synergistically with cell wall degrading enzymes [134], which results in a combined enzymatic lysis of the host cell wall and membrane leakage, processes that significantly contribute to the antagonistic action of Trichoderma mycoparasites [130].

\section{Three-Partite Interactions: Crosstalk between Different Partners}

Under field conditions, we cannot anticipate separate dual interactions between plant and pathogens, plant and BCA, or pathogen and BCA; rather, a complex network of interactions that involves multiple players is expected, and hence, investigating and understanding the three-way interactions between plant, BCA and pathogen is of high interest (Figure 2). Studying such tripartite systems can reveal important crosstalk between different interacting partners, which might not happen in bipartite interactions.

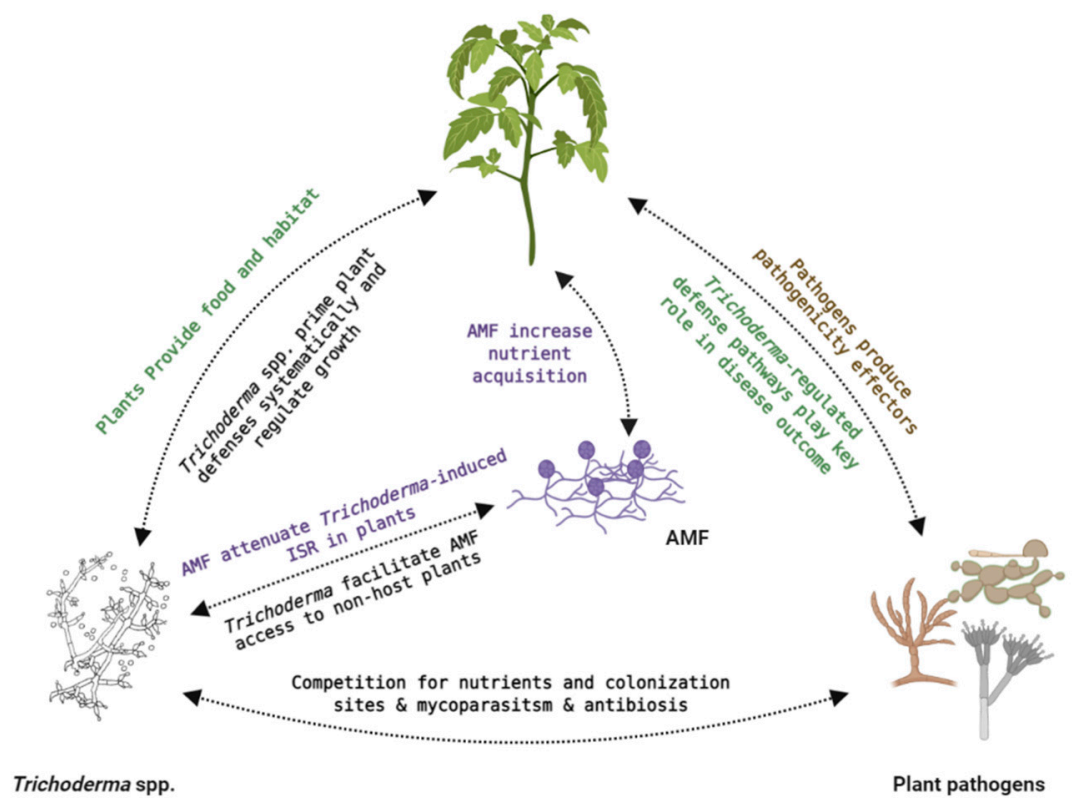

Figure 2. A schematic diagram displaying simplified glimpse of possible crosstalks between Trichoderma spp., plant pathogens, other beneficial microbes (i.e., arbuscular mycorrhizal fungi (AMF)) and plants.

In plants, nitric oxide (NO) is important for several cellular functions including defense against microbes. Using a tripartite interaction system, it was revealed that T. asperelloides had the ability to switch off NO production in $A$. thaliana roots infected with Fusarium oxysporum. NO levels in $A$. thaliana roots were monitored by diaminofluorescein fluorescence visualization and revealed that when $A$. thaliana roots were infected with F. oxysporum alone, $\mathrm{NO}$ levels remained highly detectable for at least $120 \mathrm{~min}$, while roots treated with T. asperelloides alone showed less intense and transient $\mathrm{NO}$ formation for $10 \mathrm{~min}$, and finally roots coinfected with both F. oxysporum and T. asperelloides at the same time showed NO expression pattern similar to the T. asperelloides treatment. The drastic reduction 
in NO levels in plant roots during co-inoculation of T. asperelloides and F. oxysporum might explain failure of the pathogen to initiate disease symptoms in challenged plants [135].

Moreover, a tripartite interaction experiment between $A$. thaliana, T. asperelloides, and the leaf pathogen Pseudomonas syringae DC3000 (Pst) revealed that $A$. thaliana roots treated with T. asperelloides led to a significant increase in expression of several Pst defense genes in the plant leaves, confirming systemic priming of plant defenses by T. asperelloides root treatment. Among notably altered genes, in addition to several marker genes for Et/JA pathways that were upregulated, lipid transfer protein LTP4 encoding a pathogenicity related protein was highly upregulated. On the other hand, WRKY40, a transcription factor contributing to plant susceptibility to bacterial invasion, was downregulated [136]. Furthermore, proteomic analysis revealed major changes in T. atroviride proteome during double (T. atroviride + plant) or triple (T. atroviride + plant + pathogen) interactions with bean plants and the phytopathogens $B$. cinerea or $R$. solani compared to the growth of T. atroviride alone [137]. Many proteins were produced in the tripartite but not in the bipartite setup, suggesting fine-tuned response of the antagonist to the pathogen presence during its interaction with the Plant In addition to cell wall degrading enzymes, other upregulated T. atroviride proteins included a homolog of a $40 \mathrm{kDa}$ heat shock protein, suggesting stress adaptation; chitin synthase involved in the synthesis of fungal cell wall, possibly to recover the damage caused by pathogen and plant enzymes; several cyclophilin family members playing various cellular roles; a hydrophobin and ATP-binding cassette transporters performing various roles connected with survival, stress adaption, plant growth promotion, and defense [12,64,86]. Mycoparasitic interactions between T. atroviride and plant pathogens Pythium ultimum and $R$. solani were visualized in situ on cucumber seeds using $g f p$-tagged T. atroviride, and revealed that activation of biocontrol related genes and formation of special infection structures happened during seed germination [138]. Similarly, a tripartite interaction experiment between T. virens, F. oxysporum, and tomato was used to study the mechanism by which $T$. virens regulated induced systemic resistance (ISR) in plants [139]. While treatment of two-week old tomato seedlings with either T. virens spores cultured on barley grains (BGS) or with T. virens cell-free culture filtrate (CF) significantly lowered Fusarium wilt disease incidence in tomato, further examination of disease incidence and defense gene expression revealed BGS primed ISR via JA, whereas CF primed ISR via SA. In another tripartite interaction study between T. atroviride, tomato seedlings, and the phytopathogen Phytophthora cinnamomi, T. atroviride proved able to outgrow the oomycete in the competition for available space and nutrients from both the medium and root exudates, shielding the seedlings from root rot symptoms. In the same study, it was suggested that plant root exudates are likely to play a key role in biocontrol by inducing T. atroviride growth and sporulation assisting the BCA in the competition for space and nutrients [140].

Plant defense responses to the invasion of pathogenic nematodes in the presence of T. harzianum T-79 revealed that T-79 differentially primed SA and JA mediated responses depending on the infection stage. Initially, T-79 primed the SA pathway, mounting a fast fortification of plant immunity against invasion. Later, when nematodes suppressed JA-mediated plant root defenses to establish infection, T-79 empowered plant immunity by priming this pathway to counteract the defense-suppressive effects of the nematodes. Finally, when nematodes established their infection, T-79 activated plant SA-mediated defenses in a local and systemic manner [141].

In addition to studying disease progression and mounted defense responses in plants, tripartite interaction experiments could be used to study microbial signaling not only between antagonists and pathogens but also between different beneficial microorganisms in the presence of plants. Along these lines, a study on the relationship between the two symbionts T. harzianum and the arbuscular mycorrhizal (AM) fungus Glomus sp. in potato plantlets revealed that the AM fungus increased phosphorus uptake; however, the host plant received less phosphorus as a result of the disruption of the external and internal AM fungal hyphal continuity due to T. harzianum mycoparasitism [142]. This 
highlights the importance of the nature of relationship and outcome of the interaction between different plant-beneficial microbes and how this complex network of interactions might directly or indirectly impact plant health and growth. T. harzianum's ability to influence AM function and viability may also indirectly affect the plant performance by interfering with the source-sink relationship between the AM and its host Plant Similarly, it was revealed that co-inoculation of T. harzianum and AMF, resulted in attenuated priming of plant-induced systemic resistance compared with plants inoculated only with T. harzianum [143]. However, other reports indicated compatible relationship between Trichoderma spp. and AM fungi promoting plant growth and nutrient acquisition [144-146]. The combined application of AMF with T. viride improved P uptake and increased P content on Helianthus annuus roots and shoots in comparison to a single application of either of the beneficial microbes [146]. Combined application of both symbionts improved several growth parameters such as plant height, shoot biomass, root length, leaf area, and oil content. Similar findings were reported during combined inoculation of different AM and T. viride on onion (Allium cepa) [144]. Furthermore, T. harzianum T34 facilitated successful colonization of AM fungi to non-host plants such as A. thaliana and Brassica napus (rapeseed) and improved their productivity during combined applications [147]. Clearly further research is needed to explore the nature and molecular signaling between Trichoderma and AMF in regulating plant growth and defense pathways.

\section{Conclusions and Perspectives}

Despite coming a long way since Trichoderma was originally discovered in 1794 and its ability to be used as BCA was recognized in 1930s, extensive research and commercialization of some Trichoderma strains such as BCAs, the full potential of this remarkable genus has not yet been reached. To take the utilization of Trichoderma and other similar microbial BCAs to the next level, we must first try to better understand their physiology, behavior, and crosstalk with different pathogens and plants under different conditions. In vitro studies that search for, evaluate, and understand the antagonistic potential of different BCAs against various pathogens provided valuable information but another equally important field is the crosstalk of different partners sharing the same ecological niche. In this regard, we find that tripartite interaction studies between Trichoderma, plant and pathogens provide a valuable tool to better understand the underlying signaling during these interactions. However, we must note that even tripartite interaction studies should be considered as a reductionist approach, compared with real field conditions, which harbor more complex networks of interactions between different plants and their native microbiota, insects, BCAs, and pathogens. All of these interactions are also in turn affected by abiotic factors such as drought, temperature, humidity, chemical residues, and soil fertility. Recent advances in molecular biology such as genetic editing tools and advances in metabolomic analysis provide great opportunities for major breakthroughs to identify and validate important effectors playing key roles in the context of Trichoderma interactions. Advances in other areas such as formulations, shelf life, and compatibility with integrated pest management programs would increase the confidence and popularity of Trichoderma-based products among growers. Deciphering more of the biocontrol complex network of signaling under conditions that come as close as possible to natural conditions and identifying the spoken languages (proteins, VOCs, SMs, etc.) between Trichoderma, plants, and pathogens will enable us to successfully intervene with advanced molecular tools to improve the efficacy and consistency of Trichoderma biocontrol strategies and harness the full potential of this amazing genus.

Author Contributions: A.A. drafted the paper and designed the figures. L.W. supervised the work and provided insights. Both authors revised and approved the final manuscript. All authors have read and agreed to the published version of the manuscript. 
Acknowledgments: The authors apologize to colleagues whose work expanded our understanding of the topic of this review, but could not be cited due to space constraints. This work was supported by a postdoctoral fellowship from University of Fribourg and by a Swiss Government Excellence Scholarship for Foreign Scholars from the Swiss State Secretariat for Education, Research and Innovation (SERI) to AA, and by the Swiss National Science Foundation (grant 179310 to LW).

Conflicts of Interest: The authors declare no conflict of interest.

\section{References}

1. Tilman, D. The Greening of the Green Revolution. Nature 1998, 396, 211-212. [CrossRef]

2. Tilman, D. Global Environmental Impacts of Agricultural Expansion: The Need for Sustainable and Efficient Practices. Proc. Natl. Acad. Sci. USA 1999, 96, 5995-6000. [CrossRef] [PubMed]

3. Mukherjee, P.K.; Horwitz, B.A.; Herrera-Estrella, A.; Schmoll, M.; Kenerley, C.M. Trichoderma Research in the Genome Era. Annu. Rev. Phytopathol. 2013, 51, 105-129. [CrossRef] [PubMed]

4. Harman, G.E. Overview of Mechanisms and Uses of Trichoderma Spp. Phytopathology 2006, 96, 190-194. [CrossRef] [PubMed]

5. Harman, G.E.; Howell, C.R.; Viterbo, A.; Chet, I.; Lorito, M. Trichoderma Species-Opportunistic, Avirulent Plant Symbionts. Nat. Rev. Microbiol. 2004, 2, 43-56. [CrossRef] [PubMed]

6. Woo, S.L.; Ruocco, M.; Vinale, F.; Nigro, M.; Marra, R.; Lombardi, N.; Pascale, A.; Lanzuise, S.; Manganiello, G.; Lorito, M. Trichoderma-Based Products and Their Widespread Use in Agriculture. Open Mycol. J. 2014, 8, 71-126. [CrossRef]

7. Schmidt, R.; Etalo, D.W.; de Jager, V.; Gerards, S.; Zweers, H.; de Boer, W.; Garbeva, P. Microbial Small Talk: Volatiles in Fungal-Bacterial Interactions. Front. Microbiol. 2016, 6, 1495. [CrossRef] [PubMed]

8. Keller, N.P.; Turner, G.; Bennett, J.W. Fungal Secondary Metabolism. From Biochemistry to Genomics. Nat. Rev. Microbiol. 2005, 3, 937-948. [CrossRef]

9. Bais, H.P.; Weir, T.L.; Perry, L.G.; Gilroy, S.; Vivanco, J.M. The Role of Root Exudates in Rhizosphere Interactions With Plants and Other Organisms. Annu. Rev. Plant Biol. 2006, 57, 233-266. [CrossRef]

10. Contreras-Cornejo, H.A.; Macías-Rodríguez, L.; Cortés-Penagos, C.; López-Bucio, J. Trichoderma virens, a Plant Beneficial Fungus, Enhances Biomass Production and Promotes Lateral Root Growth through an Auxin-Dependent Mechanism in Arabidopsis. Plant Physiol. 2009, 149, 1579-1592. [CrossRef]

11. Bonfante, P.; Genre, A. Interactions in Mycorrhizal Symbiosis. Nat. Commun. 2010, 1, 1-11. [CrossRef]

12. Ramírez-Valdespino, C.A.; Casas-Flores, S.; Olmedo-Monfil, V. Trichoderma as a Model to Study Effector-like Molecules. Front. Microbiol. 2019, 10, 1-14. [CrossRef] [PubMed]

13. Tandon, A.; Fatima, T.; Shukla, D.; Tripathi, P.; Srivastava, S.; Singh, P.C. Phosphate Solubilization by Trichoderma Koningiopsis (NBRI-PR5) under Abiotic Stress Conditions. J. King Saud. Univ. Sci. 2020, 32, 791-798. [CrossRef]

14. Oljira, A.M.; Hussain, T.; Waghmode, T.R.; Zhao, H.; Sun, H.; Liu, X.; Wang, X.; Liu, B. Trichoderma Enhances Net Photosynthesis, Water Use Efficiency, and Growth of Wheat (Triticum aestivum L.) under Salt Stress. Microorganisms 2020, 8, 1565. [CrossRef]

15. Zhang, S.; Xu, B.; Gan, Y. Seed Treatment with Trichoderma Longibrachiatum T6 Promotes Wheat Seedling Growth under Nacl Stress through Activating the Enzymatic and Nonenzymatic Antioxidant Defense Systems. Int. J. Mol. Sci. 2019, 20, 3729. [CrossRef]

16. Elkelish, A.A.; Alhaithloul, H.A.S.; Qari, S.H.; Soliman, M.H.; Hasanuzzaman, M. Pretreatment with Trichoderma harzianum Alleviates Waterlogging-Induced Growth Alterations in Tomato Seedlings by Modulating Physiological, Biochemical, and Molecular Mechanisms. Environ. Exp. Bot. 2020, 171, 103946. [CrossRef]

17. De Sousa, T.P.; Chaibub, A.A.; da Silva, G.B.; de Filippi, M.C.C. Trichoderma Asperellum Modulates Defense Genes and Potentiates Gas Exchanges in Upland Rice Plants. Physiol. Mol. Plant Pathol. 2020, 112, 101561. [CrossRef]

18. Poveda, J. Trichoderma Parareesei Favors the Tolerance of Rapeseed (Brassica napus L.) to Salinity and Drought Due to a Chorismate Mutase. Agronomy 2020, 10, 118. [CrossRef]

19. Sun, X.; Sun, M.; Chao, Y.; Wang, H.; Pan, H.; Yang, Q.; Cui, X.; Lou, Y.; Zhuge, Y. Alleviation of Lead Toxicity and Phytostimulation in Perennial Ryegrass by the Pb-Resistant Fungus Trichoderma asperellum SD-5. Funct. Plant Biol. 2020. [CrossRef] [PubMed]

20. Salas-marina, M.A.; Silva-flores, M.A.; Uresti-rivera, E.E.; Castro-longoria, E.; Herrera-estrella, A.; Casas-flores, S. Colonization of Arabidopsis Roots by Trichoderma atroviride Promotes Growth and Enhances Systemic Disease Resistance through Jasmonic Acid/Ethylene and Salicylic Acid Pathways. Eur. J. Plant Pathol. 2011, 15-26. [CrossRef]

21. Yedidia, I.; Benhamou, N. Induction of Defense Responses in Cucumber Plants (Cucumis sativus L.) by the Biocontrol Agent Trichoderma harzianum. Appl. Environ. Microbiol. 1999, 65, 1061-1070. [CrossRef]

22. Yedidia, I.; Benhamou, N.; Kapulnik, Y.; Chet, I. Induction and Accumulation of PR Proteins Activity during Early Stages of Root Colonization by the Mycoparasite Trichoderma harzianum Strain T-203. Plant. Physiol. Biochem. 2000, 38, 863-873. [CrossRef]

23. Martínez-Medina, A.; Fernández, I.; Sánchez-Guzmán, M.J.; Jung, S.C.; Pascual, J.A.; Pozo, M.J. Deciphering the Hormonal Signalling Network behind the Systemic Resistance Induced by Trichoderma Harzianum in Tomato. Front. Plant Sci. 2013, 4, 1-12. [CrossRef]

24. Coppola, M.; Diretto, G.; Digilio, M.C.; Woo, S.L.; Giuliano, G.; Molisso, D.; Pennacchio, F.; Lorito, M.; Rao, R. Transcriptome and Metabolome Reprogramming in Tomato Plants by Trichoderma harzianum Strain T22 Primes and Enhances Defense Responses against Aphids. Front. Physiol. 2019, 10. [CrossRef] [PubMed] 
25. La Spada, F.; Stracquadanio, C.; Riolo, M.; Pane, A.; Cacciola, S.O. Trichoderma Counteracts the Challenge of Phytophthora nicotianae Infections on Tomato by Modulating Plant Defense Mechanisms and the Expression of Crinkler, Necrosis-Inducing Phytophthora Protein 1, and Cellulose-Binding Elicitor Lectin Pathogenic Effecto. Front. Plant Sci. 2020, 11, 1-16. [CrossRef]

26. Rivera-Méndez, W.; Obregón, M.; Morán-Diez, M.E.; Hermosa, R.; Monte, E. Trichoderma asperellum Biocontrol Activity and Induction of Systemic Defenses against Sclerotium cepivorum in Onion Plants under Tropical Climate Conditions. Biol. Control 2020, 141, 104145. [CrossRef]

27. Saxena, A.; Mishra, S.; Ray, S.; Raghuwanshi, R.; Singh, H.B. Differential Reprogramming of Defense Network in Capsicum annum L. Plants Against Colletotrichum truncatum Infection by Phyllospheric and Rhizospheric Trichoderma Strains. J. Plant Growth Regul. 2020, 39, 751-763. [CrossRef]

28. Ho, C.-L.; Tan, Y.-C.; Yeoh, K.-A.; Ghazali, A.-K.; Yee, W.-Y.; Hoh, C.-C. De Novo Transcriptome Analyses of Host-Fungal Interactions in Oil Palm (Elaeis guineensis Jacq.). BMC Genom. 2016, 17, 66. [CrossRef]

29. Chacón, M.R.; Rodríguez-Galán, O.; Benítez, T.; Sousa, S.; Rey, M.; Llobell, A.; Delgado-Jarana, J. Microscopic and Transcriptome Analyses of Early Colonization of Tomato Roots by Trichoderma harzianum. Int. Microbiol. 2007, 10, 19-27. [CrossRef]

30. Martínez-Medina, A.; Fernández, I.; Pescador, L.; Romero-Puertas, M.C.; Pozo, M.J. Trichoderma harzianum triggers an early and transient burst of nitric oxide and the upregulation of PHYTOGB1 in tomato roots. Plant Signal. Behav. 2019, 14, 9. [CrossRef]

31. Lamdan, N.-L.; Shalaby, S.; Ziv, T.; Kenerley, C.M.; Horwitz, B. Secretome of Trichoderma Interacting with Maize Roots: Role in Induced Systemic Resistance. Mol. Cell. Proteom. 2015, 14, 1054-1063. [CrossRef]

32. Brotman, Y.; Landau, U.; Cuadros-Inostroza, Á.; Takayuki, T.; Fernie, A.R.; Chet, I.; Viterbo, A.; Willmitzer, L. Trichoderma-Plant Root Colonization: Escaping Early Plant Defense Responses and Activation of the Antioxidant Machinery for Saline Stress Tolerance. PLoS Pathog. 2013, 9. [CrossRef]

33. Morán-Diez, E.; Rubio, B.; Domínguez, S.; Hermosa, R.; Monte, E.; Nicolás, C. Transcriptomic Response of Arabidopsis thaliana after 24h Incubation with the Biocontrol Fungus Trichoderma harzianum. J. Plant Physiol. 2012, 169, 614-620. [CrossRef] [PubMed]

34. Shoresh, M.; Harman, G.E. The Molecular Basis of Shoot Responses of Maize Seedlings to Trichoderma harzianum T22 Inoculation of the Root: A Proteomic Approach. Plant. Physiol. 2008, 147, 2147-2163. [CrossRef] [PubMed]

35. Taki, N.; Sasaki-sekimoto, Y.; Obayashi, T.; Kikuta, A.; Kobayashi, K. 12-Oxo-Phytodienoic Acid Triggers Expression of a Distinct Set of Genes and Plays a Role in Wound-Induced Gene Expression in Arabidopsis 1 [W]. Plant Physiol. 2005, 139, 1268-1283. [CrossRef] [PubMed]

36. Shigenaga, A.M.; Berens, M.L.; Tsuda, K.; Argueso, C.T. Towards Engineering of Hormonal Crosstalk in Plant Immunity. Curr. Opin. Plant Biol. 2017, 38, 164-172. [CrossRef] [PubMed]

37. Jaroszuk-ściseł, J.; Tyśkiewicz, R.; Nowak, A.; Ozimek, E.; Majewska, M.; Hanaka, A.; Tyśkiewicz, K.; Pawlik, A.; Janusz, G. Phytohormones (Auxin, Gibberellin) and ACC Deaminase in Vitro Synthesized by the Mycoparasitic Trichoderma DEMTKZ3A0 Strain and Changes in the Level of Auxin and Plant Resistance Markers in Wheat Seedlings Inoculated with This Strain Conidia. Int. J. Mol. Sci. 2019, 20, 4923. [CrossRef] [PubMed]

38. Bilal, S.; Shahzad, R.; Khan, A.L.; Kang, S.M.; Imran, Q.M.; Al-Harrasi, A.; Yun, B.W.; Lee, I.J. Endophytic Microbial Consortia of Phytohormones-Producing Fungus Paecilomyces Formosus Lhl10 and Bacteria Sphingomonas Sp. Lk11 to Glycine max 1. Regulates Physio-Hormonal Changes to Attenuate Aluminum and Zinc Stresses. Front. Plant Sci. 2018, 9, 1-18. [CrossRef]

39. Tiwari, S.; Prasad, V.; Chauhan, P.S.; Lata, C. Bacillus amyloliquefaciens Confers Tolerance to Various Abiotic Stresses and Modulates Plant Response to Phytohormones through Osmoprotection and Gene Expression Regulation in Rice. Front. Plant Sci. 2017, 8, 1-13. [CrossRef]

40. Ngumbi, E.; Kloepper, J. Bacterial-Mediated Drought Tolerance: Current and Future Prospects. Appl. Soil Ecol. 2016, 105, 109-125. [CrossRef]

41. Saloheimo, M.; Pakula, T.M. The Cargo and the Transport System: Secreted Proteins and Protein Secretion in Trichoderma reesei (Hypocrea jecorina). Microbiology 2012, 158, 46-57. [CrossRef] [PubMed]

42. Kottb, M.; Gigolashvili, T.; Großkinsky, D.K.; Piechulla, B. Trichoderma Volatiles Effecting Arabidopsis: From Inhibition to Protection against Phytopathogenic Fungi. Front. Microbiol. 2015, 6, 1-14. [CrossRef] [PubMed]

43. Martínez-Medina, A.; Del Mar Alguacil, M.; Pascual, J.A.; Van Wees, S.C.M. Phytohormone Profiles Induced by Trichoderma Isolates Correspond with Their Biocontrol and Plant Growth-Promoting Activity on Melon Plants. J. Chem. Ecol. 2014, 40, 804-815. [CrossRef] [PubMed]

44. Lee, S.; Yap, M.; Behringer, G.; Hung, R.; Bennett, J.W. Volatile Organic Compounds Emitted by Trichoderma Species Mediate Plant Growth. Fungal Biol. Biotechnol. 2016, 1-14. [CrossRef] [PubMed]

45. Wonglom, P.; Ito, S.I.; Sunpapao, A. Volatile Organic Compounds Emitted from Endophytic Fungus Trichoderma asperellum T1 Mediate Antifungal Activity, Defense Response and Promote Plant Growth in Lettuce (Lactuca sativa). Fungal Ecol. 2020, 43, 100867. [CrossRef]

46. Martinez-Medina, A.; Van Wees, S.C.M.; Pieterse, C.M.J. Airborne Signals by Trichoderma Fungi Stimulate Iron Uptake Responses in Roots Resulting in Priming of Jasmonic Acid-Dependent Defences in Shoots of Arabidopsis thaliana and Solanum lycopersicum. Plant. Cell Environ. 2017. [CrossRef]

47. Garnica-vergara, A.; Barrera-ortiz, S.; Mu, E.; Raya-gonz, J. The Volatile 6-Pentyl-2 H -Pyran-2-One from Trichoderma atroviride Regulates Arabidopsis thaliana Root Morphogenesis via Auxin Signaling and ETHYLENE INSENSITIVE 2 Functioning. New Phytol. 2015, 209, 1496-1512. [CrossRef] 
48. Vinale, F.; Sivasithamparam, K.; Ghisalberti, E.L.; Marra, R.; Barbetti, M.J.; Li, H.; Woo, S.L.; Lorito, M. A Novel Role for Trichoderma Secondary Metabolites in the Interactions with Plants. Physiol. Mol. Plant Pathol. 2008, 72, 80-86. [CrossRef]

49. Carillo, P.; Woo, S.L.; Comite, E.; El-nakhel, C.; Rouphael, Y.; Fusco, G.M.; Borzacchiello, A.; Lanzuise, S.; Vinale, F. Application of Trichoderma harzianum, 6-Pentyl- $\alpha$-Pyrone and Plant Biopolymer Formulations Modulate Plant Metabolism and Fruit Quality of Plum Tomatoes. Plants 2020, 9, 771. [CrossRef]

50. Kishimoto, K.; Matsui, K.; Ozawa, R.; Takabayashi, J. Volatile 1-Octen-3-Ol Induces a Defensive Response in Arabidopsis thaliana. J. Gen. Plant Pathol. 2007, 73, 35-37. [CrossRef]

51. Contreras-Cornejo, H.A.; Macías-Rodríguez, L.; Herrera-Estrella, A.; López-Bucio, J. The 4-Phosphopantetheinyl Transferase of Trichoderma virens Plays a Role in Plant Protection against Botrytis cinerea through Volatile Organic Compound Emission. Plant. Soil 2014, 379, 261-274. [CrossRef]

52. Malmierca, M.; Mccormick, S.; Cardoza, R.; Monte, E.; Alexander, N.; Gutiérrez, S. Trichodiene Production in a Trichoderma harzianum Erg1- Silenced Strain Provides Evidence of the Importance of the Sterol Biosynthetic Pathway in Inducing Plant Defense-Related Gene Expression. Mol. Plant.-Microbe Interact. 2015, 28. [CrossRef] [PubMed]

53. Malmierca, M.; Mccormick, S.; Cardoza, R.; Alexander, N.; Monte, E.; Gutiérrez, S. Production of Trichodiene by Trichoderma harzianum Alters the Perception of This Biocontrol Strain by Plants and Antagonized Fungi. Environ. Microbiol. 2015, 17, 2628-2646. [CrossRef] [PubMed]

54. Rotblat, B.; Enshell-seijffers, D.; Gershoni, J.M.; Schuster, S.; Avni, A. Identification of an Essential Component of the Elicitation Active Site of EIX Protein Elicitor Identification of an Essential Component of the Elicitation Active Site of the EIX Protein Elicitor. Plant. J. 2003, 32, 1049-1055. [CrossRef] [PubMed]

55. Yu, C.; Dou, K.; Wang, S.; Wu, Q.; Ni, M.; Zhang, T.; Lu, Z.; Tang, J.; Chen, J. Elicitor Hydrophobin Hyd1 Interacts with Ubiquilin1-like to Induce Maize Systemic Resistance. J. Integr. Plant Biol. 2020, 62, 509-526. [CrossRef] [PubMed]

56. Saravanakumar, K.; Fan, L.; Fu, K.; Yu, C.; Wang, M. Cellulase from Trichoderma harzianum Interacts with Roots and Triggers Induced Systemic Resistance to Foliar Disease in Maize. Nat. Publ. Gr. 2016, 1-18. [CrossRef]

57. Vinale, F.; Manganiello, G.; Nigro, M.; Mazzei, P.; Piccolo, A.; Pascale, A.; Ruocco, M.; Marra, R.; Lombardi, N.; Lanzuise, S.; et al. A Novel Fungal Metabolite with Beneficial Properties for Agricultural Applications. Molecules 2014, 19, 9760-9772. [CrossRef]

58. Cai, F.; Yu, G.; Wang, P.; Wei, Z.; Fu, L.; Shen, Q.; Chen, W. Harzianolide, a Novel Plant Growth Regulator and Systemic Resistance Elicitor from Trichoderma harzianum. Plant. Physiol. Biochem. 2013, 73, 106-113. [CrossRef]

59. Djonović, S.; Vargas, W.A.; Kolomiets, M.V.; Horndeski, M.; Wiest, A.; Kenerley, C.M. A Proteinaceous Elicitor Sm1 from the Beneficial Fungus Trichoderma virens Is Required for Induced Systemic Resistance in Maize. Plant. Physiol. 2007, 145, 875-889. [CrossRef]

60. Djonović, S.; Pozo, M.J.; Dangott, L.J.; Howell, C.R.; Kenerley, C.M. A Proteinaceous Elicitor Sm1 from the Beneficial Fungus Trichoderma virens Is Required for Induced Systemic Resistance in Maize. Mol. Plant Microbe Interact. 2006, 19, 838-853. [CrossRef]

61. Yu, W.; Mijiti, G.; Huang, Y.; Fan, H.; Wang, Y.; Liu, Z. Functional Analysis of Eliciting Plant Response Protein Epl1-Tas from Trichoderma asperellum ACCC30536. Sci. Rep. 2018, 8, 1-13. [CrossRef] [PubMed]

62. Gomes, E.V.; Ulhoa, C.J.; Cardoza, R.E.; Silva, R.N.; Gutiérrez, S. Involvement of Trichoderma harzianum Epl-1 Protein in the Regulation of Botrytis Virulence- and Tomato Defense-Related Genes. Front. Plant Sci. 2017, 8, 880. [CrossRef] [PubMed]

63. Brotman, Y.; Briff, E.; Viterbo, A.; Chet, I. Role of Swollenin, an Expansin-Like Protein from Trichoderma, in Plant Root Colonization. Plant. Physiol. 2008, 147, 779-789. [CrossRef] [PubMed]

64. Ruocco, M.; Lanzuise, S.; Lombardi, N.; Woo, S.L.; Vinale, F.; Marra, R.; Varlese, R.; Manganiello, G.; Pascale, A.; Scala, V.; et al. Multiple Roles and Effects of a Novel Trichoderma Hydrophobin. Mol. Plant Microbe Interact. 2015, 28, 167-179. [CrossRef]

65. Vinale, F.; Flematti, G.; Sivasithamparam, K.; Lorito, M.; Marra, R.; Skelton, B.W.; Ghisalberti, E.L. Harzianic Acid, an Antifungal and Plant Growth Promoting Metabolite from Trichoderma harzianum. J. Nat. Prod. 2009, 72, 2032-2035. [CrossRef]

66. Vinale, F.; Strakowska, J.; Mazzei, P.; Piccolo, A.; Marra, R.; Lombardi, N.; Manganiello, G.; Pascale, A.; Woo, S.L.; Lorito, M. Cremenolide, a New Antifungal, 10-Member Lactone from Trichoderma cremeum with Plant Growth Promotion Activity. Nat. Prod. Res. 2016, 30, 2575-2581. [CrossRef]

67. Pocurull, M.; Fullana, A.M.; Ferro, M.; Valero, P.; Escudero, N.; Saus, E.; Gabaldón, T.; Sorribas, F.J. Commercial Formulates of Trichoderma Induce Systemic Plant Resistance to Meloidogyne incognita in Tomato and the Effect Is Additive to That of the Mi-1.2 Resistance Gene. Front. Microbiol. 2020, 10, 1-10. [CrossRef]

68. Marra, R.; Coppola, M.; Pironti, A.; Grasso, F.; Lombardi, N.; Errico, G.; Sicari, A.; Censi, S.B.; Woo, S.L.; Rao, R.; et al. The Application of Trichoderma Strains or Metabolites Alters the Olive Leaf Metabolome and the Expression of Defense-Related Genes. J. Fungi 2020, 6, 369. [CrossRef]

69. Basińska-Barczak, A.; Błaszczyk, L.; Szentner, K. Plant Cell Wall Changes in Common Wheat Roots as a Result of Their Interaction with Beneficial Fungi of Trichoderma. Cells 2020, 9, 2319. [CrossRef]

70. Lombardi, N.; Caira, S.; Troise, A.D.; Scaloni, A.; Vitaglione, P.; Vinale, F.; Marra, R.; Salzano, A.M.; Lorito, M.; Woo, S.L. Trichoderma Applications on Strawberry Plants Modulate the Physiological Processes Positively Affecting Fruit Production and Quality. Front. Microbiol. 2020, 11, 1-17. [CrossRef]

71. Alfano, G.; Ivey, M.L.L.; Cakir, C.; Bos, J.I.B.; Miller, S.A.; Madden, L.V.; Kamoun, S.; Hoitink, H.A.J. Systemic Modulation of Gene Expression in Tomato by Trichoderma hamatum 382. Phytopathology 2007, 97, 429-437. [CrossRef] [PubMed] 
72. Pel, M.J.C.; Pieterse, C.M.J. Microbial Recognition and Evasion of Host Immunity. J. Exp. Bot. 2013, 64, 237-1248. [CrossRef] [PubMed]

73. Hermosa, R.; Viterbo, A.; Chet, I.; Monte, E. Plant-Beneficial Effects of Trichoderma and of Its Genes. Microbiology 2012, 158, 17-25. [CrossRef] [PubMed]

74. Boller, T.; Felix, G. A Renaissance of Elicitors: Perception of Microbe-Associated Molecular Patterns and Danger Signals by Pattern-Recognition Receptors. Annu. Rev. Plant Biol. 2009, 60, 379-407. [CrossRef]

75. Perazzolli, M.; Dagostin, S.; Ferrari, A.; Elad, Y.; Pertot, I. Induction of Systemic Resistance against Plasmopara viticola in Grapevine by Trichoderma harzianum T39 and Benzothiadiazole. Biol. Control 2008, 47, 228-234. [CrossRef]

76. Palmieri, M.C.; Perazzolli, M.; Matafora, V.; Moretto, M.; Bachi, A.; Pertot, I. Proteomic Analysis of Grapevine Resistance Induced by Trichoderma harzianum T39 Reveals Specific Defence Pathways Activated against Downy Mildew. J. Exp. Bot. 2012, 63, 6237-6251. [CrossRef]

77. Piel, J.; Atzorn, R.; Gäbler, R.; Kühnemann, F.; Boland, W. Cellulysin from the Plant Parasitic Fungus Trichoderma viride Elicits Volatile Biosynthesis in Higher Plants via the Octadecanoid Signalling Cascade. FEBS Lett. 1997, 416, 143-148. [CrossRef]

78. Hermosa, R.; Belén Rubio, M.; Cardoza, R.E.; Nicolás, C.; Monte, E.; Gutiérrez, S. The Contribution of Trichoderma to Balancing the Costs of Plant Growth and Defense. Int. Microbiol. 2013, 16, 69-80. [CrossRef]

79. Segarra, G.; Van Der Ent, S.; Trillas, I.; Pieterse, C.M.J. MYB72, a Node of Convergence in Induced Systemic Resistance Triggered by a Fungal and a Bacterial Beneficial Microbe. Plant. Biol. 2009, 11, 90-96. [CrossRef]

80. Siddaiah, C.N.; Satyanarayana, N.R.; Mudili, V. Elicitation of Resistance and Associated Defense Responses in Trichoderma hamatum Induced Protection against Pearl Millet Downy Mildew Pathogen. Nat. Publ. Gr. 2017, 1-18. [CrossRef]

81. Singh, U.B.; Malviya, D.; Wasiullah; Singh, S.; Pradhan, J.K.; Singh, B.P.; Roy, M.; Imram, M.; Pathak, N.; Baisyal, B.M.; et al. Bio-Protective Microbial Agents from Rhizosphere Eco-Systems Trigger Plant Defense Responses Provide Protection against Sheath Blight Disease in Rice (Oryza sativa L.). Microbiol. Res. 2016, 192, 300-312. [CrossRef] [PubMed]

82. Martinez-Medina, A.; Flors, V.; Heil, M.; Mauch-Mani, B.; Pieterse, C.M.J.; Pozo, M.J.; Ton, J.; van Dam, N.M.; Conrath, U. Recognizing Plant Defense Priming. Trends Plant Sci. 2016, 21, 818-822. [CrossRef] [PubMed]

83. Rasmann, S.; Bennett, A.; Biere, A.; Karley, A.; Guerrieri, E. Root Symbionts: Powerful Drivers of Plant above- and Belowground Indirect Defences. Insect Sci. 2017, 1-14. [CrossRef]

84. Coppola, M.; Cascone, P.; Chiusano, M.L.; Colantuono, C.; Lorito, M.; Pennacchio, F.; Rao, R.; Woo, S.L.; Guerrieri, E.; Digilio, M.C. Trichoderma harzianum Enhances Tomato Indirect Defense against Aphids. Insect Sci. 2017, 1-9. [CrossRef]

85. Battaglia, D.; Bossi, S.; Cascone, P.; Digilio, M.C.; Prieto, J.D.; Fanti, P.; Guerrieri, E.; Iodice, L.; Lingua, G.; Lorito, M.; et al. Tomato below Ground-above Ground Interactions: Trichoderma longibrachiatum Affects the Performance of Macrosiphum euphorbiae and Its Natural Antagonists. Mol. Plant Microbe Interact. 2013, 26, 1249-1256. [CrossRef]

86. Ruocco, M.; Lanzuise, S.; Vinale, F.; Marra, R.; Turrà, D.; Woo, S.L.; Lorito, M. Identification of a New Biocontrol Gene in Trichoderma atroviride: The Role of an ABC Transporter Membrane Pump in the Interaction with Different Plant-Pathogenic Fungi. Mol. Plant Microbe Interact. 2009, 22, 291-301. [CrossRef]

87. Vinale, F.; Sivasithamparam, K.; Ghisalberti, E.L.; Marra, R.; Woo, S.L.; Lorito, M. Trichoderma-Plant-Pathogen Interactions. Soil Biol. Biochem. 2008, 40,1-10. [CrossRef]

88. Zeilinger, S.; Gruber, S.; Bansal, R.; Mukherjee, P.K. Secondary Metabolism in Trichoderma—Chemistry Meets Genomics. Fungal Biol. Rev. 2016, 30, 74-90. [CrossRef]

89. Srivastava, M.; Shahid, M. Trichoderma Genome to Genomics: A Review. J. Data Min. Genom. Proteom. 2014, 5, 3-6. [CrossRef]

90. Khalili, E.; Javed, M.A.; Huyop, F.; Rayatpanah, S.; Jamshidi, S.; Wahab, R.A. Evaluation of Trichoderma Isolates as Potential Biological Control Agent against Soybean Charcoal Rot Disease Caused by Macrophomina Phaseolina. Biotechnol. Biotechnol. Equip. 2016, 30, 479-488. [CrossRef]

91. Chaparro, A.P.; Carvajal, L.H.; Orduz, S. Fungicide Tolerance of Trichoderma asperelloides and T. harzianum Strains. Agric. Sci. 2011, 2, 301-307. [CrossRef]

92. Widmer, T.L. Compatibility of Trichoderma asperellum Isolates to Selected Soil Fungicides. Crop Prot. 2019, 120, 91-96. [CrossRef]

93. Hirpara, D.G.; Gajera, H.P. Molecular Heterozygosity and Genetic Exploitations of Trichoderma Inter-Fusants Enhancing Tolerance to Fungicides and Mycoparasitism against Sclerotium rolfsii Sacc. Infect. Genet. Evol. 2018, 66, 26-36. [CrossRef]

94. Alfiky, A.; Eldenary, M. Molecular Characterization and Biocontrol-Traits Evaluation of Trichoderma virens TVH3 against Fusarium oxysporum, the Causal Agent of Tomato Wilt. Egypt. J. Bot. 2018. [CrossRef]

95. Alfiky, A. Effects of Ultraviolet Irradiation on the in Vitro Antagonistic Potential of Trichoderma Spp. against Soil-Borne Fungal Pathogens. Heliyon 2019, 5. [CrossRef]

96. Steyaert, M.; Ridgway, H.J.; Elad, Y.; Stewart, A. Genetic basis of mycoparasitism: A mechanism of biological control by species of Trichoderma. N. Z. J. Crop Hortic. Sci. 2003, 31, 281-291. [CrossRef]

97. Kubicek, C.P.; Herrera-estrella, A.; Seidl-seiboth, V.; Martinez, D.A.; Druzhinina, I.S.; Thon, M.; Zeilinger, S.; Casas-flores, S.; Horwitz, B.A.; Mukherjee, P.K.; et al. Comparative Genome Sequence Analysis Underscores Mycoparasitism as the Ancestral Life Style of Trichoderma. Genome Biol. 2011, 12, R40. [CrossRef]

98. Inbar, J.; Chet, I. A Newly Isolated Lectin from the Plant Pathogenic Fungus Sclerotium rolfsii: Purification, Characterization and Role in Mycoparasitism. Microbiology 1994, 140 Pt 3, 651-657. [CrossRef] 
99. Zeilinger, S.; Omann, M. Trichoderma Biocontrol: Signal Transduction Pathways Involved in Host Sensing and Mycoparasitism. Gene Regul. Syst. Bio. 2007, 1, 227-234. [CrossRef]

100. Omann, M.R.; Lehner, S.; Rodríguez, C.E.; Brunner, K.; Zeilinger, S. The Seven-Transmembrane Receptor Gpr1 Governs Processes Relevant for the Antagonistic Interaction of Trichoderma atroviride with Its Host. Microbiology 2012, 158, 107-118. [CrossRef]

101. Li, N.; Alfiky, A.; Vaughan, M.M.; Kang, S. Stop and Smell the Fungi: Fungal Volatile Metabolites Are Overlooked Signals Involved in Fungal Interaction with Plants. Fungal Biol. Rev. 2016, 30, 134-144. [CrossRef]

102. Hung, R.; Lee, S.; Bennett, J.W. Fungal Volatile Organic Compounds and Their Role in Ecosystems. Appl. Microbiol. Biotechnol. 2015, 3395-3405. [CrossRef]

103. Li, N.; Alfiky, A.; Wang, W.; Islam, M.; Nourollahi, K.; Liu, X.; Kang, S. Volatile Compound-Mediated Recognition and Inhibition Between Trichoderma Biocontrol Agents and Fusarium oxysporum. Front. Microbiol. 2018, 9, 1-16. [CrossRef]

104. Li, N.; Islam, M.T.; Kang, S. Secreted Metabolite-Mediated Interactions between Rhizosphere Bacteria and Trichoderma Biocontrol Agents. PLoS ONE 2019, 14, e0227228. [CrossRef]

105. Seidl, V.; Song, L.; Lindquist, E.; Gruber, S.; Koptchinskiy, A.; Zeilinger, S.; Schmoll, M.; Martínez, P.; Sun, J.; Grigoriev, I.; et al. Transcriptomic Response of the Mycoparasitic Fungus Trichoderma atroviride to the Presence of a Fungal Prey. BMC Genom. 2009, 10, 567. [CrossRef]

106. Atanasova, L.; Le Crom, S.; Gruber, S.; Coulpier, F.; Seidl-Seiboth, V.; Kubicek, C.P.; Druzhinina, I.S. Comparative Transcriptomics Reveals Different Strategies of Trichoderma Mycoparasitism. BMC Genom. 2013, 14, 121. [CrossRef]

107. Sharma, V.; Salwan, R.; Sharma, P.N.; Kanwar, S.S. Elucidation of Biocontrol Mechanisms of Trichoderma harzianum against Different Plant Fungal Pathogens: Universal yet Host Specific Response. Int. J. Biol. Macromol. 2017, 95, 72-79. [CrossRef]

108. Guzmán-Guzmán, P.; Alemán-Duarte, M.I.; Delaye, L.; Herrera-Estrella, A.; Olmedo-Monfil, V. Identification of Effector-like Proteins in Trichoderma Spp. and Role of a Hydrophobin in the Plant-Fungus Interaction and Mycoparasitism. BMC Genet. 2017, 18, 16. [CrossRef]

109. Zeilinger, S.; Reithner, B.; Scala, V.; Peissl, I.; Lorito, M.; Mach, R.L.; Vegetale, S.P. Signal Transduction by Tga3, a Novel G Protein $\alpha$ Subunit of Trichoderma atroviride. Appl. Environ. Microbiol. 2005, 71, 1591-1597. [CrossRef]

110. Omann, M.; Zeilinger, S. How a Mycoparasite Employs G-Protein Signaling: Using the Example of Trichoderma. J. Signal. Transduct. 2010, 2010, 123126. [CrossRef]

111. Li, L.; Wright, S.J.; Krystofova, S.; Park, G.; Borkovich, K.A. Heterotrimeric G Protein Signaling in Filamentous Fungi. Annu. Rev. Microbiol. 2007, 61, 423-452. [CrossRef] [PubMed]

112. Syrovatkina, V.; Alegre, K.O.; Dey, R.; Huang, X.Y. Regulation, Signaling, and Physiological Functions of G-Proteins. J. Mol. Biol. 2016, 428, 3850-3868. [CrossRef] [PubMed]

113. Yu, X.; Liu, H.; Niu, X.; Akhberdi, O.; Wei, D.; Wang, D.; Zhu, X. The Ga1-CAMP Signaling Pathway Controls Conidiation, Development and Secondary Metabolism in the Taxol-Producing Fungus Pestalotiopsis microspora. Microbiol. Res. 2017, $203,29-39$. [CrossRef]

114. Herpoel-Gimbert, I.; Margeot, A.; Dolla, A.; Jan, G.; Molle, D.; Lignon, S.; Mathis, H.; Sigoillot, J.C.; Monot, F.; Asther, M. Comparative Secretome Analyses of Two Trichoderma reesei RUT-C30 and CL847 Hypersecretory Strains. Biotechnol. Biofuels 2008, 1, 18. [CrossRef]

115. Rocha, V.; Maeda, R.; Pereira, N.; Kern, M.; Elias, L.; Simister, R.; Steele-King, C.; Gómez, L.D.; McQueen-Mason, S.J. Characterization of the Cellulolytic Secretome of Trichoderma harzianum during Growth on Sugarcane Bagasse and Analysis of the Activity Boosting Effects of Swollenin. Biotechnol. Prog. 2016, 32, 327-336. [CrossRef]

116. Grinyer, J.; McKay, M.; Nevalainen, H.; Herbert, B.R. Fungal Proteomics: Initial Mapping of Biological Control Strain Trichoderma harzianum. Curr. Genet. 2004, 45, 163-169. [CrossRef] [PubMed]

117. De Lima, F.B.; Félix, C.; Osório, N.; Alves, A.; Vitorino, R.; Domingues, P.; Correia, A.; da Silva Ribeiro, R.T.; Esteves, A.C. Secretome Analysis of Trichoderma atroviride T17 Biocontrol of Guignardia Citricarpa. Biol. Control 2016, 99, 38-46. [CrossRef]

118. Suárez, M.B.; Sanz, L.; Chamorro, M.I.; Rey, M.; González, F.J.; Llobell, A.; Monte, E. Proteomic Analysis of Secreted Proteins from Trichoderma Harzianum: Identification of a Fungal Cell Wall-Induced Aspartic Protease. Fungal Genet. Biol. 2005, 42, 924-934. [CrossRef]

119. Ramada, M.H.S.; Steindorff, A.S.; Bloch, C.; Ulhoa, C.J. Secretome Analysis of the Mycoparasitic Fungus Trichoderma Harzianum ALL 42 Cultivated in Different Media Supplemented with Fusarium solani Cell Wall or Glucose. Proteomics 2016, 16, 477-490. [CrossRef]

120. Yang, H.H.; Yang, S.L.; Peng, K.C.; Lo, C.T.; Liu, S.Y. Induced Proteome of Trichoderma harzianum by Botrytis cinerea. Mycol. Res. 2009, 113, 924-932. [CrossRef]

121. Jeleń, H.; Błaszczyk, L.; Chełkowski, J.; Rogowicz, K.; Strakowska, J. Formation of 6-n-Pentyl-2H-Pyran-2-One (6-PAP) and Other Volatiles by Different Trichoderma Species. Mycol. Prog. 2014, 13, 589-600. [CrossRef]

122. Siddiquee, S.; Cheong, B.E.; Taslima, K.; Kausar, H.; Hasan, M.M. Separation and Identification of Volatile Compounds from Liquid Cultures of Trichoderma harzianum by GC-MS Using Three Different Capillary Columns. J. Chromatogr. Sci. 2012, 50, 358-367. [CrossRef]

123. Stoppacher, N.; Kluger, B.; Zeilinger, S.; Krska, R.; Schuhmacher, R. Identification and Profiling of Volatile Metabolites of the Biocontrol Fungus Trichoderma atroviride by HS-SPME-GC-MS. J. Microbiol. Methods 2010, 81, 187-193. [CrossRef] 
124. Chen, J.L.; Sun, S.Z.; Miao, C.P.; Wu, K.; Chen, Y.W.; Xu, L.H.; Guan, H.L.; Zhao, L.X. Endophytic Trichoderma Gamsii YIM PH30019: A Promising Biocontrol Agent with Hyperosmolar, Mycoparasitism, and Antagonistic Activities of Induced Volatile Organic Compounds on Root-Rot Pathogenic Fungi of Panax notoginseng. J. Ginseng Res. 2015, 40, 315-324. [CrossRef]

125. Hermosa, R.; Cardoza, R.E.; Rubio, M.B.; Gutiérrez, S.; Monte, E. Secondary Metabolism and Antimicrobial Metabolites of Trichoderma. Biotechnol. Biol. Trichoderma 2014, 125-137. [CrossRef]

126. Mukherjee, P.K.; Horwitz, B.A.; Kenerley, C.M. Secondary Metabolism in Trichoderma-A Genomic Perspective. Microbiology 2012, 158, 35-45. [CrossRef]

127. Vinale, F.; Marra, R.; Scala, F.; Ghisalberti, E.L.; Lorito, M.; Sivasithamparam, K. Major Secondary Metabolites Produced by Two Commercial Trichoderma Strains Active against Different Phytopathogens. Lett. Appl. Microbiol. 2006, 43, 143-148. [CrossRef]

128. Li, M.F.; Li, G.H.; Zhang, K.Q. Non-Volatile Metabolites from Trichoderma Spp. Metabolites 2019, 9, 58. [CrossRef]

129. Reino, J.L.; Guerrero, R.F.; Hernández-Galán, R.; Collado, I.G. Secondary Metabolites from Species of the Biocontrol Agent Trichoderma. Phytochem. Rev. 2007, 7, 89-123. [CrossRef]

130. Karlsson, M.; Atanasova, L.; Jensen, D.F.; Zeilinger, S. Necrotrophic Mycoparasites and Their Genomes. Microbiol. Spectr. 2017, 5, 1-21. [CrossRef]

131. Hoffmeister, D.; Keller, N.P. Natural Products of Filamentous Fungi: Enzymes, Genes, and Their Regulation. Nat. Prod. Rep. 2007, 24, 393-416. [CrossRef]

132. Wiest, A.; Grzegorski, D.; Xu, B.W.; Goulard, C.; Rebuffat, S.; Ebbole, D.J.; Bodo, B.; Kenerley, C. Identification of Peptaibols from Trichoderma virens and Cloning of a Peptaibol Synthetase. J. Biol. Chem. 2002, 277, 20862-20868. [CrossRef]

133. Chugh, J.K.; Wallace, B.A. Peptaibols: Models for Ion Channels. Biochem. Soc. Trans. 2001, 29, 565-570. [CrossRef]

134. Schirmbock, M.; Lorito, M.; Wang, Y.L.; Hayes, C.K.; Arisan-Atac, I.; Scala, F.; Harman, G.E.; Kubicek, C.P. Parallel Formation and Synergism of Hydrolytic Enzymes and Peptaibol Antibiotics, Molecular Mechanisms Involved in the Antagonistic Action of Trichoderma harzianum against Phytopathogenic Fungi. Appl. Environ. Microbiol. 1994, 60, 4364-4370. [CrossRef]

135. Gupta, K.J.; Mur, L.A.J.; Brotman, Y. Trichoderma asperelloides Suppresses Nitric Oxide Generation Elicited by Fusarium oxysporum in Arabidopsis Roots. Mol. Plant Microbe Interact. 2014, 27, 307-314. [CrossRef]

136. Brotman, Y.; Lisec, J.; Méret, M.; Chet, I.; Willmitzer, L.; Viterbo, A. Transcript and Metabolite Analysis of the Trichoderma-Induced Systemic Resistance Response to Pseudomonas syringae in Arabidopsis thaliana. Microbiology 2012, 158, 139-146. [CrossRef]

137. Marra, R.; Ambrosino, P.; Carbone, V.; Vinale, F.; Woo, S.L.; Ruocco, M.; Ciliento, R.; Lanzuise, S.; Ferraioli, S.; Soriente, I.; et al. Study of the Three-Way Interaction between Trichoderma atroviride, Plant and Fungal Pathogens by Using a Proteomic Approach. Curr. Genet. 2006, 50, 307-321. [CrossRef]

138. Lu, Z.; Tombolini, R.; Woo, S.; Zeilinger, S.; Lorito, M.; Jansson, J.K. In Vivo Study of Trichoderma-Pathogen-Plant Interactions, Using Constitutive and Inducible Green Fluorescent Protein Reporter Systems. Appl. Environ. Microbiol. 2004, 70, 3073-3081. [CrossRef]

139. Jogaiah, S.; Abdelrahman, M.; Tran, L.P. Different Mechanisms of Trichoderma virens -Mediated Resistance in Tomato against Fusarium Wilt Involve the Jasmonic and Salicylic Acid Pathways. Mol. Plant Pathol. 2017, 9, 870-882. [CrossRef]

140. Macías-Rodríguez, L.; Guzmán-Gómez, A.; García-Juárez, P.; Contreras-Cornejo, H.A. Trichoderma atroviride Promotes Tomato Development and Alters the Root Exudation of Carbohydrates, Which Stimulates Fungal Growth and the Biocontrol of the Phytopathogen Phytophthora cinnamomi in a Tripartite Interaction System. FEMS Microbiol. Ecol. 2018, 94, 1-11. [CrossRef]

141. Martínez-Medina, A.; Fernandez, I.; Lok, G.B.; Pozo, M.J.; Pieterse, C.M.J.; Van Wees, S.C.M. Shifting from Priming of Salicylic Acid- to Jasmonic Acid-Regulated Defences by Trichoderma Protects Tomato against the Root Knot Nematode Meloidogyne incognita. New Phytol. 2017, 213, 1363-1377. [CrossRef]

142. De Jaeger, N.; de la Providencia, I.E.; Dupré de Boulois, H.; Declerck, S. Trichoderma harzianum Might Impact Phosphorus Transport by Arbuscular Mycorrhizal Fungi. FEMS Microbiol. Ecol. 2011, 77, 558-567. [CrossRef]

143. Martínez-Medina, A.; Roldán, A.; Albacete, A.; Pascual, J.A. The Interaction with Arbuscular Mycorrhizal Fungi or Trichoderma harzianum Alters the Shoot Hormonal Profile in Melon Plants. Phytochemistry 2011, 72, 223-229. [CrossRef]

144. Metwally, R.A.; Al-Amri, S.M. Individual and Interactive Role of Trichoderma viride and Arbuscular Mycorrhizal Fungi on Growth and Pigment Content of Onion Plants. Lett. Appl. Microbiol. 2020, 70, 79-86. [CrossRef]

145. Szczałba, M.; Kopta, T.; Gąstoł, M.; Sękara, A. Comprehensive Insight into Arbuscular Mycorrhizal Fungi, Trichoderma Spp. and Plant Multilevel Interactions with Emphasis on Biostimulation of Horticultural Crops. J. Appl. Microbiol. 2019, 127, 630-647. [CrossRef]

146. Yadav, A.; Yadav, K.; Aggarwal, A. Impact of Arbuscular Mycorrhizal Fungi with Trichoderma viride and Pseudomonas Fluorescens on Growth, Yield and Oil Content in Helianthus annuus L. J. Essent. Oil-Bearing Plants 2015, 18, 444-454. [CrossRef]

147. Poveda, J.; Hermosa, R.; Monte, E.; Nicolás, C. Trichoderma harzianum Favours the Access of Arbuscular Mycorrhizal Fungi to Non-Host Brassicaceae Roots and Increases Plant Productivity. Sci. Rep. 2019, 9, 1-11. [CrossRef] 